\title{
Fertilizer Encapsulation to Support Food Security: Review
}

\author{
*Retno Sulistyo Dhamar Lestari \\ Department of Chemical Engineering \\ Indonesia Center of Execelenc for Food Security (I-CEFORY), \\ UNTIRTA (Local Food Innovation) \\ Banten, Indonesia \\ *rsdlestari@untirta.ac.id
}

\author{
Jayanudin \\ Department of Chemical Engineering \\ Indonesia Center of Execelenc for Food Security (I-CEFORY), \\ UNTIRTA (Local Food Innovation) \\ Banten, Indonesia \\ jayanudin@untirta.ac.id
}

\begin{abstract}
Food security consists of four main pillars such as food availability, food access, food utilization, and food stability. Increased food production is the most important factor because it is sufficient to meet everyone's food needs. Food availability is associated with the modification and efficiency of fertilizer use that is the focus of this article. The efficient use of fertilizers has an impact on increasing crop production. Conventional fertilizers are easily dissolved in water and are only absorbed by $18-20 \%$; the rest is transported by water flow or settles in the soil causing water pollution and disturbance to soil structure. Low absorption efficiency causes a decrease in crop production and can be a problem for food security. Low absorption efficiency causes a decrease in crop production and can be a problem for food security. The solution is to create a controlled fertilizer release technology (CRF). Nutrients are released from the CRF can be optimally absorbed by plants, thereby increasing productivity and reducing the risk of environmental pollution. CRF technology can save energy, time and operating costs. This review article is a technology of controlled release fertilizer (CRF) that supports food security.
\end{abstract}

Keywords-controlled release, encapsulation, food security, fertilizer, slow release

\section{INTRODUCTION}

Food security is a condition for the fulfillment of food from the Country to individuals, which is reflected in the availability of sufficient food, both in quantity and quality, safe, diverse, nutritious, equitable, affordable, not contrary to religion, culture and society, to be able to live healthy, actively and productively sustainably [1]. an increasing population must be accompanied by an increase in food sources. Food security is one of the most important problems throughout the world and even in Indonesia. a country's productivity is related to sufficient food needs for its citizens.

Food security index (Indeks Ketahanan Pangan/IKP) is an indicator to determine the food security situation. the global food security index for Indonesia had a score of 46.8 in 2012 and increased in 2018 with a score of 54.7 (the highest score is 100) [2]. Food security is related to food availability, which is one of the four pillars of food security. Food availability can be achieved if crop production increases significantly. Crop productivity is influenced by climate (weather) and also the absorption efficiency of nutrients by roots and then circulated to all parts of the plant.

Fertilizers with the composition of $\mathrm{N}, \mathrm{P}$, and $\mathrm{K}$ are essential nutrients for plant growth [3]. Nutrient use efficiency (NUE) can be increased due to nutrient balance in the soil and can be achieved by adding fertilizer. However, the use of conventional fertilizers can result in environmental pollution and damage the soil structure caused by an abundance of fertilizer that is not absorbed by plants because of its high solubility to water. This factor makes conventional fertilizers have a low nutrient use efficiency (NUE) [3]. One solution to improve the efficiency of nutrient absorption by plants so can increase crop productivity is by fertilizer technology with controlled release. Controlled release fertilizer technology has been developed by researchers to increase crop production in support of food security. This article reviews the function of controlled release fertilizer for food security because it can increase food availability.

\section{A. Food security in Indonesia and Banten}

Indonesia's population continues to increase and can reach 261 million in 2019 [4]. An increase in population has an impact on increasing food demand and availability. abundant natural resources can provide enormous benefits in ensuring food availability. Information about food security listed in UU No.18 / 2012 for food and PP No. 17/2015 for food security and nutrition.

The law contains information on food security that is more accurate, comprehensive and well-organized to support efforts to prevent and manage food and nutrition insecurity. For this reason, the Indonesian government has created a road map for food security and food insecurity. Increased food demand and population, as well as slowed economic growth, food and nutrition security will continue to be a major concern [5]

Food security is defined as the ease for everyone to have physical and economic access to get sufficient, safe and nutritious food in order to have an active and healthy life. Food insecurity occurs if everyone does not have access to adequate, nutritious and safe food. food insecurity occurs due to unavailability of food, deficient purchasing power, or improper use at the household level [6]. 
In 2017, the global food security index for Indonesia was ranked 69th out of 113 countries. this ranking increased compared to 2016 which was rated 71 . The parameters measured were availability, affordability, safety, and quality of food (EIU 2017). Global Hunger Index (GHI) compiled by the International Food Policy Research Institute (IFPRI) with four aspects to assess a country's food security such as the proportion of undernourishment, toddler wasting, toddler stunting, and infant mortality. The GHI index shows that Indonesia is ranked 72nd out of 119 countries. Another food security index is the Ice Bowl Index (RBI) to assess a country's capacity to overcome food security challenges and Indonesia is ranked 10th out of 15 countries in Asia Pacific [5].

The concept of food security and insecurity is based on three pillars such as food availability, food access, and food utilization. The explanation of the three pillars according to the food security agency (Badan Ketahanan Pangan) from the Ministry of Agriculture is as follows:

a) Food availability : Conditions for the availability of food from domestic production, food reserves, and food supplies from imports and food aid.

b) Access to food : The ability to obtain sufficient nutritious food through various sources such as own supply, purchases, loans and food aid.

c) Food Utilization : Food utilization refers to the use of food and the ability of individuals to absorb and metabolize nutrients. Food utilization includes how to store, process and prepare food, water safety for drinking and cooking, hygiene conditions in eating habits (especially for individuals with special food needs), food distribution in the household according to individual needs (growth, pregnancy and breastfeeding) ), and the health status of each household member.

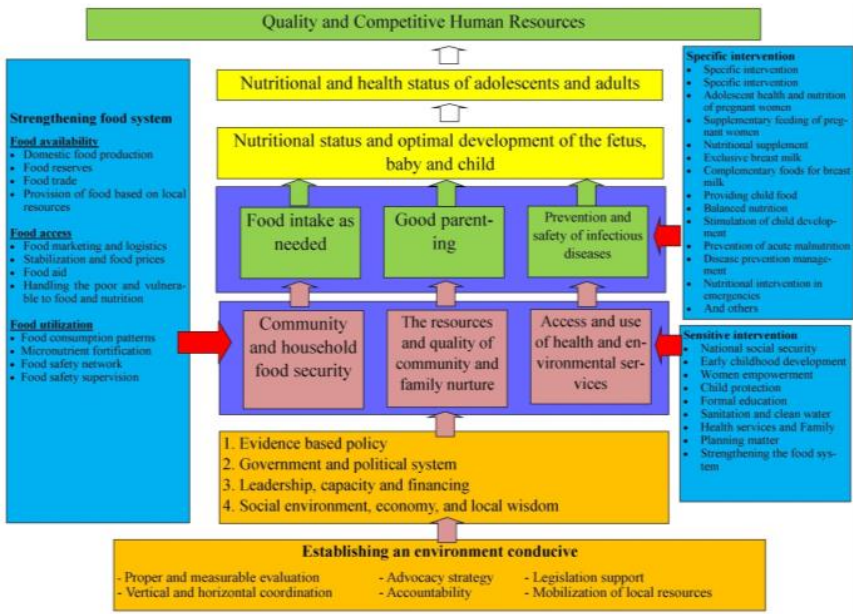

Source: [5]

Fig. 1. Scheme of food security

Figure 1 explains that the performance of each pillar is reflected in terms of food supply stability, community access to food, and food utilization. If one of these pillars does not function, the consequences will have a negative impact on nutrition and health. Factors related to food and general care practices have contributed to the condition of public health.
The level of food security in Indonesia is assessed in the form of a food security index (Indeks Ketahanan Pangan/IKP) compiled by the Food Security Agency (Badan Ketahanan Pangan), the ministry of agriculture. Data obtained from the city / district level. The compilation indicator is derived from three pilllars of food security. IKP assessment results from Banten province are listed in Table 1.

TABLE I. FOOD SECURITY INDEX IN BANTEN FOR 2017

\begin{tabular}{|c|c|c|c|c|}
\hline \multirow[t]{2}{*}{ Districts/City } & \multicolumn{4}{|c|}{ Dimensions of food security } \\
\hline & $\begin{array}{c}\text { Food } \\
\text { availability }\end{array}$ & $\begin{array}{c}\text { Food } \\
\text { access }\end{array}$ & $\begin{array}{c}\text { Food } \\
\text { utilization }\end{array}$ & IKP \\
\hline 1. Pandeglang & 83.73 & 76.39 & 68.61 & 76.24 \\
\hline 2. Lebak & 85.26 & 77.03 & 64.05 & 75.43 \\
\hline 3. $\quad$ Tangerang & 87.88 & 83.24 & 73.45 & 81.58 \\
\hline 4. $\quad$ Serang & 89.28 & 81.15 & 66.75 & 79.08 \\
\hline 5. Tangerang City & 89.92 & 84.7 & 77.38 & 84.00 \\
\hline 6. Cilegon City & 87.91 & 81.68 & 74.44 & 81.34 \\
\hline 7. $\quad$ Serang City & 86.67 & 78.1 & 70.88 & 78.54 \\
\hline $\begin{array}{l}\text { 8. South Tangerang } \\
\text { City }\end{array}$ & 96.22 & 86.54 & 75.41 & 86.05 \\
\hline Banten & 88.81 & 82.09 & 72.14 & 81.03 \\
\hline
\end{tabular}

Table I. showed that the index of food security (Indeks Ketahanan Pangan/IKP) in Banten province was 81.03. The value of food security index for the high category comes from South Tangerang city, Tangerang district, and Cilegon city, while the medium category is from Serang Regency, Serang City, Pandeglang Regency, and Lebak Regency. As for the national scale, the index of food security in cities and districts in Banten is far below other regions in Indonesia. For example, for the area of Tangerang Regency it is ranked 250, Serang Regency is in position 15 (Food Security Agency (Badan Ketahanan Pangan), Ministry of Agriculture, 2018).

The three pillars of food security are the most important factors in overcoming food insecurity. Food availability is the most important pillar because it is to fulfill food supply needs. Increased food productivity can overcome the crisis of food availability. One effort that needs to be done is the efficient use of fertilizer consumption. fertilizer consumption for plant nutrients can reach 30 to $50 \%$ for main grain crops [6]. Without additional plant nutrients from fertilizers can only produce half of total production. Inorganic fertilizers have a big role in increasing the nutrient content in the soil.

Absorption of nutrients such as nitrogen $(\mathrm{N})$, phosphorus $(\mathrm{P})$, and Potassium $(\mathrm{K})$ for conventional fertilizers is only around $18-40 \%$ while the rest are in the environment and can become waste which can also damage the soil structure. solubility and low absorption of conventional fertilizers require the addition of fertilizers repeatedly and can certainly increase operating costs during the process of planting to harvest. Technological innovation continues to be developed to improve the efficiency of nutrient absorption by plants and one of the special concerns is slow / controlled release fertilizer. this type of fertilizer is modified by coating the fertilizer by organic polymers (thermo- plastic and resin) and inorganic layers (based on sulfur and minerals) [8]. Increased efficiency in the use of nutrients from slow / controlled release fertilizers is expected to increase crop production to overcome food insecurity. 


\section{B. Slow/controlled release fertilizer}

Slow/controlled release of fertilizer is fertilizer that releases nutrients to the soil for a certain time and is longer than traditional fertilizers so that it can provide nutrients to be absorbed by substantially extended plants. [9][10]. This fertilizer is different from conventional fertilizer, the slow/controlled release fertilizer releases nutrients gradually and controlled by a certain amount. [10][11][12].

controlled release fertilizers are fertilizers that are packaged with a layer of polymer, biopolymer, or sulfur material [10]. This layer (membrane) serves to retain moisture and regulate diffusion release of fertilizers. The amount of nutrients released depends on the wall thickness of the microcapsule (fertilizer coating) [13]. The process of coating fertilizer or the formation of microcapsules is carried out by the encapsulation process [14].

The basic principle of slow release fertilizer is to release fertilizer gradually to maximize the absorption of nutrients by plants and minimize losses due to leaching, evaporation, and excessive grass growth. Slow release fertilizer is usually made by mixing fertilizer with fibrous organic material and binders [14]. Figure 2 shows that the illustration of the fertilizer release process, in which the media (usually water) diffuses through the membrane layer (microcapsule wall) dissolves fertilizer and exits back through the microcapsule wall.

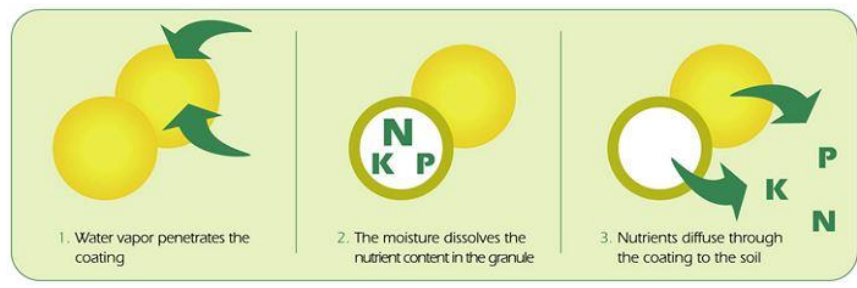

Source:[15]

Fig. 2. Mechanism of fertilizer release from microcapsules.

The diffusion rate is determined by soil temperature. The rate of release increases when the temperature rises, and also the rate of plant absorption. Other factors, such as soil type, humidity, $\mathrm{pH}$, and microbial activity do not affect the rate of release [16]

The main problem in the production of polymer-coated fertilizers (fertilizer encapsulation) is the choice of coating material and the process used to implement it [17]. The release of nutrients through the polymer membrane is not significantly affected by soil properties, such as $\mathrm{pH}$, salinity, texture, microbial activity, redox potential, ionic strength of the soil solution, but rather by the permeability of temperature and humidity of the polymer layer. Thus, it is possible to predict the release of nutrients from polymercoated fertilizers for a certain period of time.

Many studies have been developed with the aim of increasing the efficiency of nutrient use through the generate of controlled release and slow release fertilizers. According to [14], the type of slow/controlled release of fertilizer are as follows:

- Sulfur coated urea (SCU)

- Sulfur compound fertilizers

- Resin coating fertilizer
- Urea formaldehyde

- Urea and nitrification inhibitors

- Melt tower granulation compound fertilizer

- Compound fertilizer granulation spraying urea melt

- Chemically modified biomass urea coating for controlled release

- Bulk mixed fertilizer

\section{Preparation method for fertilizer encapsulation}

In general, the process of forming a slow/controlled release fertilizer is divided into two processes, namely using a polymer wall material and a composite method. The method of forming a slow/controlled release fertilizer with a polymer or biopolymer as a wall material can be carried out by spray drying, in situ polymerization, emulsion crosslinking, and mixing. As for the composite method, this process is carried out by adding other components such as minerals to the polymer.

The function of the composite method is to increase physical strength and retain nutritional capacity. For example, fertilizer encapsulation using the in-situ polymerization method is carried out by Rochmadi et al [18]. As the reaction time increases the microcapsule wall becomes hardened and forms a fertilizer microcapsule. Encapsulation with the composite process has also been carried out, as by Sarkar, et al [19]. The process is urea fertilizer soaked in a gel made from nanoclay-polymer composites (NCPCs). The method of forming NCPCs is done by adding acrylic acid, acrylamide, and clay. Hereafter, the N, N'-methylene bisacrylamide crosslinker is added and followed by the addition of a radical initiator so that a polymerization reaction occurs and a microcapsule is formed

\section{Slow/controlled release fertilizer can increase crop productivity}

Fertilizer consumption in Indonesia continues to increase every year, data from PT. Pupuk Indonesia recorded fertilizer sales of 8.956 million tons and an increase of $7 \%$ in the third quarter of 2018 from last year. Consumption continues to increase making fertilizer production until the third quarter of 2018 also increased by $12 \%$ to 5.64 million tolls for all fertilizers. This increase in production aims to prioritize the need for fertilizer for food in securing the needs of farmers. [20].

The high consumption of fertilizer is not matched by its efficiency, conventional fertilizer has low nutrient use efficiency (NUE) from the ability of plants to obtain nutrients, transport it in the roots, and move to other parts of the plant. More than $50 \%$ of the nutrients from conventional fertilizers are not absorbed by plants, which can cause environmental pollution [6]. Controlled nutritional supply can reduce adverse effects on the environment; otherwise it can increase nutrient use efficiency (NUE), if the release pattern is in line with plant demand.

Increased crop production by increasing nutrient use efficiency (NUE) has been widely studied and the results are quite convincing that slow-controlled release fertilizer can increase NUE. The problem that may have to be overcome is the high production costs. This is due to the use of more raw materials. However, the period of adding new fertilizers is much reduced compared to using conventional fertilizers. 
The comparison of total operating costs when using slow/controlled release fertilizers is lower than using conventional fertilizers.

The development of slow/controlled release fertilizers must continue to be developed to reduce the high production costs. In addition, the use of slow/controlled release fertilizers can reduce the risk of pollution to the environment.

\section{CONCLUSION}

Food insecurity can be overcome with three main pillars of food security, namely the availability of abundant food, easy access to food, and appropriate use of food. One of the most important factors of food security is the availability of food that is related to crop productivity. The efficiency of nutrient absorption is very influential on increasing crop yields. Conventional fertilizers have low nutrient use efficiency (NUE) because they dissolve easily in water and release nutrients in large quantities and are not proportional to the amount of nutrients absorbed by plant roots. The remaining nutrients that are not absorbed will seep into the soil and be carried away by water. The addition of fertilizer repeatedly causes minerals/nutrients in the soil and water to be abundant so that it can cause damage to the soil structure and pollute the water. One of the solutions to increase crop production is to develop smart fertilizers, namely slow/controlled release fertilizer.

\section{ACKNOWLEDGMENT}

Authors thank to The Islamic Development Bank (IsDB) - Universitas Sultan Ageng Tirtayasa (UNTIRTA) for providing grant project and to Chemical Engineering Department, Universitas Sultan Ageng Tirtayasa for all research facilities that have been provided.

\section{REFERENCES}

[1] UU No. 18 Tahun 2012 tentang Pangan

[2] https://tirto.id/some-kuat-ketahanan-pangan-indonesia-dhNraccessed September 18, 2019

[3] Calabi-Floody M, Medina J, and Rumpel C, et al. (2018) Smart Fertilizers as a Strategy for Sustainable Agriculture.Adv. Agron. 147: 119-157

[4] https://www.bps.go.id, accessed on September 12, 2019
[5] http://bkp.pertanian.go.id/peta-ketahanan-dan-kerentananpangan.Accessed September 18, 2019

[6] Stewart WM and Roberts TL (2012) Food security and the role of fertilizer in supporting it.ProcediaEng 46: 76-82

[7] https://banten.bps.go.id, acessed on September 19, 2019

[8] Azeem B, Kushaari K, and Man ZB, et al. (2014) Review on materials \& methods to produce controlled release coated urea fertilizer. J. Control. Release 181: 11-21

[9] Fu, J., Wang, C., Chen, X., et al., (2018). Classification research and types of slow controlled release fertilizers (SRFs) used - a review, Communications in Soil Science and Plant Analysis, DOI: 10.1080/00103624.2018.1499757

[10] Ostrom, A. K., 2011. Comparing the effect of controlled-release, slow-release, and water soluble fertilizers on plant growth and nutrient leaching.Thesis.Graduate Program in Horticulture and Crop Science. The Ohio State University

[11] Liu, G., Zotarelli, L., Li, Y., Dinkins, D, et al., 2017. ControlledRelease and Slow-Release Fertilizers as Nutrient Management Tools. UF/IFAS Extension. https://edis.ifas.ufl.edu/hs1255.

[12] Krzysztof, L., Aleksandra, S., Barbara, G., et al., 2015. ControlledRelease Fertilizer Prepared Using a Biodegradable Aliphatic Copolyester of Poly(butylene succinate) and Dimerized Fatty Acid. Journal of Agricultural and Food Chemistry. 63: 2597-2605

[13] Morgan, K.T., Cushman, K.E., and S. Sato. 2009. Release Mechanisms for Slow- and Controlled-release Fertilizers and Strategies for Their Use in Vegetable Production. HortTechnology. 19:10-12

[14] Sazzad, M.H., Islam, M.T., Chowdhury, F., 2013.A review \& outlook of slow-release fertilizer.Lap Lambert Academic Publishing.Pp 1-22

[15] http://www.acefertilizer.com/info/how-does-controlled-releasefertilizer-work-1925482.html, accessed September 6, 2019

[16] http://www.acefertilizer.com/info/how-does-controlled-releasefertilizer-work-1925482.html, accessed July 18, 2019

[17] Trenkel M (2010) Advantages and disadvantages of slow- and controlled-release fertilizers and nitrification and urease inhibitors, In Slow-and controlled release and stabilized fertilizers, International Fertilizer Industry Association (IFA) Paris, France, 2010, p. 61-69.

[18] Rochmadi, Prasetya, A, and Hasokowati, W. (2010). Mechanism of Microencapsulation with Urea-Formaldehyde Polymer. Am. J. Appl. Sci 7: 739-745.

[19] Sarkar, S., Datta, S.C., and Biswas, D.R. (2014). Effect of Fertilizer Loaded Nanoclay/Superabsorbent Polymer Composites on Nitrogen and Phosphorus Release in Soil. Proc. Natl. Acad. Sci., India, Sect. B Biol. Sci. 85(2):415-421.

[20] https://ekonomi.kompas.com/read/2018/10/27/151335126/kuartal-iii2018-penjualan-pupuk-indonesia-capai-895-juta-ton). 